\title{
An Integrated Strategy for Waterfront Redevelopment Case Study: Alexandria, Egypt
}

\author{
Nermeen A. Omar, Engy H. Saeed
}

Architecture engineering department, engineering Faculty, Tanta University, Egypt nermeen_omar@f-eng.tanta.edu.eg engy_hassan@f-eng.tanta.edu.eg

\begin{abstract}
Waterfront areas are considered one of the vital and challenging urban spaces which give a great opportunity and catalyst to develop the city. Through the historical and literature studies that interested in the waterfront development, that showed the important role of the waterfront not only as a place for trade, transport and industry but also a place of entertainment, recreation and tourism. Therefore, the waterfront achieves sustainable urban development and enhances the quality of urban life. And Despite the international attention to the phenomenon of waterfront development, it has not getting the same attention in the in the Middle East, only through some individual attempts. So, the study aims to set a proposed framework based on comprehensive strategy that can be achieved by numbers of standers through a process to improve the waterfront development vision.
\end{abstract}

The result of the study showed that the waterfront area plays a significant role to redevelopment the city economically, socially and environmentally through strategic objectives; sustainability, urban integration, stakeholders partnership and efficient governance. This objective can be achieved by number of standers includes; land use, urban identity, socio-economic benefits, urban depth development, environmental quality, accessibility and place making quality. The study selected the case study Alexandria - Egypt one of the most important coastal cities which have a lot of potentials that qualifies it to be global waterfront. The study concludes some recommendations to develop Mahatet El-Raml waterfront in central district of Alexandria, which based on the proposed framework, that highlight main points which should be conceder in the future development of the waterfront.

Keywords: waterfront, sustainability, integration, urban development, redevelopment.

\section{INTRODUCTION}

The city through time played many roles essentially as a living and work place, beside its role to entertainment and a recreational place for its people, and the success of any city is how it reflects people's spirit and its culture and history [26]. Most of the cities in the beginning were located close to or on the edge of water which was a vital element to human survival and became an important and essential factor of transport, food, production and economic activities [41].

Throughout the history, the relationship began between the built and natural environment of the city regardless the type of the water whether lake, river, canal or sea .... etc. and forming the city and its waterfront. So, the waterfront can be defined as a stretched land with water direct contact. It can be a city harbor or a whole city not only a line along the edge of the water [32-9]. With the growth of the urban and turning the activities over, the water effected in the urban context formation which was obviously in the old cities which appeared in the street and block patterns. It is reflected by the shape of topography and natural features [9].

The waterfront and its importance had changed through the three waves that reflected on its development and shows in the transformation of its functions and activities, at the first wave waterfront activities was mainly the agricultural, fishing and offshore fishing, at the second wave - which started from the 18th century - there was the industrial revolution and the activities was included trade, industries, goods distribution. By the third wave which began by 20th century with post industries and information revolution era it includes many activities and functions such as leisure, tourism and recreation through the culture preservation, marine research and ecosystem investigation [11].

Because of the importance of the waterfront and its roles to enhance the city, many attempts appear by 1960 in North America for redevelopment the waterfront especially when the city transform from industrial to service. During fifties of the 20th and the cases such as Baltimore and Boston became models for the redevelopment a revitalization projects [3]. Later by 1970 , the first water development movement was presented to transform the abandoned lands of the old ports and harbors to a social, residential, economical, and recreational hub. This approach or movement of redevelopment spread for many parts of the world and the technological important with post-industrial, social and ecological interests were dominated on the redevelopments all over the world and considered the waterfront as a motive and challenge urban lands [29].

The redevelopment of the waterfront lands become global phenomenon for a sustainable city, and there are many international urban design and planning examples that proved the importance of waterfront land and their contribution to achieve a sustainable cities around the world such as Bilboa, Spain and Toronto, Canada, However this appears in the Middle East and Arabic cities hardly in rare projects, although many of the cities have a wide water sources; sea, river, golf....etc., that can be considered as an important catalyst for the development of these cities. So it is necessary to give more attention to the development and redevelopment of waterfront and improve strategies that are interested in it to reach an integrated comprehensive vision to achieve sustainable development cities.

\section{A. The Aim}

The aim of the research attempts to set a proposed framework based on comprehensive strategy that can be achieved by numbers of standers through a process to improve the waterfront development vision. The main aim of 
the research includes number of the secondary aims; identify the main objectives of the comprehensive strategy and determine the urban standers of the waterfront development. That the planners and urban designer should takes it in consideration.

\section{B. The Research Methodology}

The research methodology is based on theoretical and analytical approaches; the theoretical approach reviews literature studies and the international examples to highlight the strategy objectives and the waterfront urban standards and therefore sets a proposed framework according to this strategy and standards. The analytical approach concerned of choosing one of the waterfront city in Egypt- Mahatet ElRaml waterfront - which is considered one of the important waterfront examples at the central district of Alexandria city and applying the proposed framework to reach a development vision. Finally, the research concludes a number of results and recommendation which can be taken into account for the proposed waterfront case study and the waterfront development vision.

\section{WATERFRONT DEVELOPMENT STRATEGY}

First step for success waterfront development or redevelopment is good comprehensive strategy that balances between competing requirements; dynamic economy and sustainable social environment. By considering the Waterfront development strategy as a part of urban development strategy this strategy aims to confirm more inclusive socially responsible, integrated sustainable development and cultural and historical relevance. To achieve future success for different problems in waterfront projects there are need different development strategies to recovery for the shortage of existing methods and strategies, in order to enhance the ability to meet challenges which appear during the development process, and establish conception for the future probability development. The objectives of this comprehensive strategy are:

\section{A. Sustainability}

Sustainability is one of the most important strategic goals for urban development. It should integrate in to development planning for whole city [25]. Sustainable development is the process that meets the needs of the present without negative impact on the ability of future generation to meet their needs [25]. Consequently, establish sustainability as a strategic goal in waterfront development programs is very important to improve living conditions for citizens not only in economic and ecologic but also in preservation and social terms [17-40]. In addition, sustainable development approaches aim to maximize human welfare and create better places where people can live, work, and visit and present future residents [11-17].

Also, sustainable approaches in waterfront development consist of comprehensive framework by establishing strategies and policies that include the waterfront countenance, available resources and requirement for use. So, Sustainability goals occur by fulfills the criteria of sustainable waterfront development and integrates it in to all layers of the development process [18] and it has to controlling the decisions of all disciplines as (architecture, urban planner ....) in the development process.

\section{B. Urban integration}

The term integration may refer to; integration of past and present, integration of the objectives and constructing aims and integration of communities and location. It can be defined as a strategic goal for urban waterfront development operation. The new water development areas have to be understood as an integral part of a city's urban structure [14]. Urban integration refers to strategic and physical planning of the city, and it also refers to the integration of the citizen of urban reality not only through the physical and functional benefits but also by including ability to create new social interaction and new opportunities for employment [14].

Achieving urban integration of the waterfront development strategies depends on some factors:

- Urban planning integration is essential for cohesive development, means considering the relation of urban planning of the waterfront development with the conceptual planning of the city.

- The criteria of the selection of the new development areas which has to be consistent with the general context of the city and supports its development planes [14].

- Integrated infrastructure investments by coordinating the waterfront development process with the city's major infrastructure investments, such as, public transport, basic urban infrastructure system, social serveries [14].

\section{Stakeholder partnership}

Stakeholder partnership means all the investors and parties which included in the urban development process and what are their responsibilities. Coordinating the roles of the participating parties and their responsibilities is considered strategic goal which essential to the success of the waterfront development process [32]. Each participating party performs different function in the process according to their specifications [32]. The participating parties can be classified as:

-Public organization (central and local government): its main role is focus on providing many services to the development area, and it is the main actor of dissension making and management the process. Also, it has important role in ensure that the environmental and social consideration take into account.

-Private sectors: the main goal of the privet sector is to make profits [32]. The planning in public privet partnership speeds the development [8].

It takes place by coordinating efforts between the public administration and private sector which considered a key element to the development process success [23].

Waterfront development is complex and difficult and requires a huge amount of investments, so integrate the public private resources in development process in order to ensure the feasibility and permanence of the implementation of the waterfront projects [12].

So, the public administration ensures the quality of the design and infrastructure [40]. The private sector role provides investment in shopping centers, recreation areas, residences projects and, offices buildings.

- Communities: public participation plays an important role 
to achieve sustainability [21]. The empowered active citizenship is a key element of the successful of waterfront development projects. When the communities sense that the project belongs to them and they recognize the importance of their vision and participation of urban development of the city [17-23]. Active citizenship in the beginning of the process is recommended with active discussion and collaboration [21].

- Non-profit organization: NGOs are independent of the government, the main aim of this is to provide non-profitable services by focusing on the social and environmental aspects. This organization need to the investments of the private sector to reach their goals.

- Professionals: waterfront development is a complex process that involves professionals of many disciplines. The integrate and exchange the information and knowledge in an international network between the different disciplines which involved in the waterfront development process is very important for the project to achieve these goals [21].

- There has to be balance and collaboration between various stakeholders [32]. It is also important to establish strategic network with stakeholders and understand the goal of the waterfront development project and fully agree with them [30-32]. Each actor should focus on these responsibilities in order to achieve a unified vision of urban development.

\section{Efficient governance}

The role of governance is very essential in waterfront development process. Good governance is considered as a strategic objective to success the waterfront development project. This is responsible for correspond the different objectives and interests of various stakeholders involves in the waterfront development process. It also enhances the capability of government and citizen to work together to achieve spatial and social integration.

There is a need to improve governance strategies to become more efficient in the process of developing waterfront. There are several factors that help to achieve that: - Adaptive management which enables the decision makers to combine the ecological, social and economic information and to have ability to adapt with environmental and economic changes.

- Achieve high level of cooperation between stakeholders and provide efficient communication system.

- High enforcement of regulation is recommended and sustainable guidelines and urban policies [39].

- Promoting a balance between the interests of the communities and the economic expectations of the investors [40].

- Well-financial management is making balance between revenue and expenses that develops the resources of the city to achieve sustainable and efficient finances, also reviewing the master plan in order to reduce the financial risks. [\40].

- Learning lessons from international experiences.

\section{URBAN WATERFRONT DEVELOPMENT STANDERS}

Many of literature studies and researches that interesting in the waterfront development were discussed many trends and principles for waterfront development. The trends of waterfront regeneration had spread from North America to the rest of the world including UK, Europe, Africa and Asian countries. Through reviewing these studies and numbers of international examples in waterfront development, the research concludes number of urban waterfront development Standards as following:

\section{A. Land uses}

\section{Land use diversity}

Diverse uses have been take place on waterfront areas, that include local business areas like industry, fishing, trade, recreation, transportation, offices and Residential areas, these uses could be formed in residential communities and the facilities of the neighborhood that consist of the main school, playgrounds, parks and stores. Or in Leisure areas which consist of recreational facilities, public parks, culture facilities, public spaces and entertainment [41].

These various uses shaped integral functions for the waterfront that offering a variety reasons to stay and visit throughout day and evening.

There are many examples as Dalian, China where the changing of land uses has high profit rate occupancy such as recreation, office and commercial uses like tourist leisure activities. This achieved through the concept of "open city" which the government allowed many investments; private and foreign [29].

Waterfront can be one of the central areas of the city with its diversity land use that makes waterfront the heart of the city's culture, social and civic life, and becomes a creative milieu based on diversity uses as in Baltimore's Inner Harbor project [20-21]. Malaysia waterfront which is designed for the public purposes by making mix used development with many housing and commercial projects [3].

So, waterfront can be one of the central areas of the city by including the diversity land uses that make waterfront the heart of the city's culture, social and civic life. For example, the project of Hamurge- Die Hafen city presents good example of land use diversity. This district is divided to quarters each one has specific categories of uses such as places for culture and creativity (oberhafen), places for commercial center and activities (uberseequartier), residential areas (Elbtorquarties), in this areas different uses are developed such as retail, hotels, services, offices and culture [25].

\section{Shifting land use}

Replacing the functions of the waterfront (to tourism and consumption industries beside the socio-economic expand with culture interest) is the generators to redevelopment of the waterfront and to the whole city and region. [29] This is appeared in the waterfront trail of the Toronto with the spatial restructuring plan which included the relocating of the existing industry and offering the place for tertiary industry to improving the economic growth. As well as in Boston, considering the seaport area as a potential investment by replacement of the historic port to multifunction area with a complex of hotels, deluxe housing, parks and culture centers [3]. 


\section{B. Urban Identity}

The urban identity is influenced essential by the natural and cultural dimensions. It is established from the interaction between the human practices towards the city areas including the waterfront areas. [6] So the urban growth and the increasing of the population affected negatively on the identity with losing the heritage and culture of the place.

The waterfront development can be considered as the identity preservation catalyst and important opportunity to represent the distinctive identity of the city. So, the success of the waterfront design and planning is in controlling the city's prosperity and its aura during all the changes through time [21-22].

Pittsburgh with its three rivers is an example for the identity conservation, the rivers of the steel and its banks were a production and industrial places while all the public life was far from the industrial banks, through time, the vision of the city and its waterfront change to attract people, and become accessible, green, beautiful and clean by establishing new projects, such as baseball park, football stadium and others on the rivers with conservation of its old industrial places [21].

Also at the Waterfront of Auckland, New Zealand (with its industry, dockyards, warehouses, gas station... since 1880) the planners preserved the industrial heritage by using many icons in the silo park such as the old cement silo, or the former shipping containers which arranged to be an attractive site for tourist in the city [25].

On the opposite, Shanghai transformed from a fishing community to a megalopolis without expressing sentimentality for the good old days. This achieved by directing the planners to a series of ambitions plans to reorient modern, cosmopolitan Shanghai [21]. But Zanzibar's Stone Town waterfront was an example of the local perspective towards old culture and heritage with its architectural character (Indian Arab, African and European features). It encouraged many organizations to concern the historic waterfront and its redevelopment with the government such as the fund by the EU which restructure the waterfront space by; relocated the industry port, preserve the ferry and passenger facilities and open many retail and public facility. These encouraged the movement of the tourists and put Zanzibar on the cultural tourist list [29].

\section{Socio-Economic Benefits}

While the waterfront area is considered as an urban advantage which attracts many investments to the surrounding territory and to the whole city, it becomes an urban structure with significant land value. These new investments must be compatible with the urban uses such as the cultural, tourism, leisure projects.

For example, the Guggenheim museum major effect to the economy of Bilbao, it raised the occupation rate of the hotels from about $20 \%$ in the weekends to full percentage. Also Baltimore waterfront revitalization plans presented about 15000 jobs and the number of the tourists has been raised. [9-26]. So, the redevelopment of the waterfront is important in the economic growth for the city, it can reach through:

\section{Long-term value}

However, considering the waterfront as a main motivation to improve the economy of the city, but it could be wasted opportunity if it exploits the best location negatively in very large and fast benefits, it called "jumpstart" waterfront renewal. These projects such as convention centers, casinos and stadiums which occupying the special location on the water' edge and screen the water benefits from the other areas. This can be observed for example in San Diego, the huge convention center and tall hotels at the bayside that becoming an empty place after any events with a shortage mixed use development in the area [21].

On the contrary, Bilbao's city where it enhances its image through redevelopment of its waterfront with many projects which get huge benefits all the year like culture and commercial projects beside real estate development as a strategic goal effects in all the city [21-27].

It is also appeared in Istanbul waterfront revitalization which adopted the short and long term; the short term has concentrated on highway construction and the green area parallel to the water. The long term as in the development of Galata port was built as a passenger port with various uses and activities through many projects like the cruise port, hotels, entertainments places, theatres and shopping malls. These gave Istanbul the national and international image with long term investments. [3] also, Toronto with a design of marginal industrial and port properties and designing green space offering a new work and living environment on 900 hectares for 100,000 people [21].

\section{Competitive advantage}

The people and investments are always attracted to all beautiful and distinctive places but trying to keep them by this image may minimize the production of a generic environment by the modern development. So the challenge of the success waterfront is to have a unique and special area by its characters and activities with modern facilities.

So, Waterfront sites provide great opportunities to develop the city, and give the city the ability to compete with other cities internationally to attract wealth in physical and human term. Competitive advantage is an essential aspect of many nations and local urban programs. While the Waterfronts have highly visible locations in most cities, its development is so important to many environmental and urban regeneration efforts. Also the successful waterfront development requires an awareness of the global process. So, distinguish setting, appropriate infrastructure and unique location at waterfront sites provides significant competitive advantage for the cities in global economy and attractive tourism [23].

This can show in the Genoa harbor with its natural shape which is considered as a powerful device for the stretching of the modern city with strong bond with the old harbor. This condition and the unique land and sea geography make the city not only a tourist and cultural destination all over the world but also a place for contemporary businesses, residences, institutions and tourists facilities [21]. Therefore, the location of the city on the water provides it a strong and unique advantage and impression, which is considered as a strong important opportunity globally without losing local 
industry.

Another example, Shanghai has become known as the world biggest cities. It has invested three times more in its urban infrastructure in response to achievement competitive advantage. The waterfront provides shanghai an important opportunity to remake the image of the city and present new face for the world [23].

\section{Business and market places}

To establish and support the business and market places in the waterfront development projects, it is an important to create optimal locations for new business. There are factors can help to achieve these goals:

- Transportation that is having direct effect on the location of business and market places and its establishment.

- land availability and cost: the available of land as a market places to own or rent is very important to support the business and investments in the waterfront projects, also the land price and land rent effect on the cost. So, less expensive land is needed.

- Labor: it is important to supplies the business with services and products because every business depend on labor.

- Infrastructure: business and market places require infrastructure to be efficient, and deliver high quality of products and services.

- Business and market location: it plays an important role in determination the prices of goods and services and the number of consumers which business will benefit from. Also agglomeration of business has an effect on the location of it. So, some businesses are located closer to other in order to the people attract toward the city center place to obtain from advantages such as; use shorter distance to benefit from all functions, variety of products, services and lower prices. Also, some business located around bigger businesses to benefit from its activities [32].

Besides that, the choices of the locations with healthy environment, job markets, culture and arts are the success keys, besides it gives a strong feel of sense of the place through active lifestyle with access to water.

\section{Urban Depth Development}

It is important to complex an indistinctive relationship between the land and the water whenever the land/water overlap zone is boarder, and the success of the waterfront and the city will increase to contain many activities with huge benefits of its water presence. So, the advantage of the water is not only from the thin line avenue along the water edge as in Malecon, Havana or Bund, Shanghai. But it can be achieved through thinking of the edge avenue with the perpendiculars of the water edge into the city [21]

Or making fingers to the water, this was shown obviously in Bilbao, Spain in the mixed uses corridors which perpendiculars on the water edge to add to the waterfront more value. [27] Another example, Boston which depends on the system of Colonial Street "fingers to the sea", that are functional extensions of its wharves [21]. So, the perpendiculars development is essential for successful planning for any waterfronts improvement.

\section{E. Accessibility}

There are many historic obstructions; physical, edges rights, flood ambits and other, that limit the access to waterfronts in many cities. Although this access has various advantages; economical, environmental, social, and it should be directed to all types of users (citizens and tourists) [21].

This success must ensure in waterfront areas from all the city direction by the network and many facilities such as public transportations, pedestrian and cycle enabling beside the private vehicles. All of that provide under a movement strategy to avoid any conflicts between all different users. This is shown in Daedalus, England [41].

Chicago waterfront and Providence city are other examples that are extend all along the river road with infrastructure that encouraged the investments, which helped to energizing the downtown and its relationship with waterfront itself. Louisville city, Kentucky, USA made the flood banks as an area for amazing recreational landscape which is considered as a link and access area between the downtown with Ohio River, this area had protected broad banks with elevated highway making a new park which is famous with its environment and social history with the river and the city. [21]

Toronto is one of the important waterfront which introduces the importance of the accessibility through a continuous green trail, it combines over 100 projects that connect over 640 kilometers shore of the Ontario lake to regenerate the waterfront areas, and create a public access for many projects such as marinas, historic places, cultural institutions and parks (almost 150 parks and peaches with 200 natural areas) [21-34].

The waterfront areas should be accessible to the entire public not only to the tourists that can be achieved by providing activities which generate people engage and directed them to the waterfront location.

\section{F. $\quad$ Place Making Quality}

\section{Livable area}

Although the pressure of the financial and the commercial development of the waterfronts, it is important to be a living city. Waterfront as a livable area is very essential to the success of the waterfront development project. It can be achieved by providing mixed uses areas, residential areas with rang of housing types and unique character, facilities and services, recreation and entertainment activities. These various uses are bringing visitors and citizens back to the waterfront edges and make waterfront vitality and livable place. Also, movement on the water creates a special level of vitality on water, it can achieve by providing costal ferry and terminals.

This appears obviously in Vancouver city and its slogan "living first", the city began the transformation of the waterfronts from industrial uses to be housing units. By the end of century, the main policy was creating places to live with regulations control building uses and mass, losing public access and maintains the waterfront edge for all public purposes [2-21].

Also, Melbourne, Australia which sets strategies concern of improving the quality of waterfront for residents and visitors through the commercial and port activities by design popular public spaces [28].

Daedatus waterfront design is another example in England 
and the access statement (2011). The key principles of the master plan design are providing high quality lively place by promote the waterfront as a place for work and live, with a range of housing types to create diversity in the community. Also, waterfront provides facilities for communities and business. In addition, create new public spaces as focus on recreational activities [40].

\section{Image}

After the waterfront becomes a globalize phenomenon to improving land development of the city, and as Short said "what sells the city is the image of the city", the image of the city become one national and international level to redevelopment the waterfront [9].

The urban character of the waterfront is a result of historical development, society thinking and the attitudes with the time passing. This issue is strongly concerned especially after the transformations of the industrial sites which reestablish the image compete with [16].

The most famous examples with unique image of the waterfront are Sydney and Bilbao, because of this both of the waterfronts become worldwide known [9].

\section{G. Environmental quality}

"Creating ecological protection areas" Unfortunately, the concern of the coast ecology in the past was ignored, and all attentions were directed to the industry and technology, but in last decades the interest and attention to this point and its importance was increased to achieve the protection of the quality of water and environment as a fundamental issue to development [40].

"Sustainable waterfront development in the future" this interest should be for the coast, waterfront lands and the city to face many challenges; global climatic variation, raise of the sea level and wastes of various uses. So the environmental protection can be achieved through selecting suitable economic - social uses and responsible usage of the resources with the assets of all decision makers [11].

Some applications are important to achieve this such as; secure the quality of water and environmental conservation of aquarium life, [8-19] reduce consumption of energy and materials, and Use green infrastructure [33], such as trees and shrubbery along green way.

These applications should achieve to reduce energy use, improve air quality, reduce the heat island and help to reduce sound transmission and local noise pollution level. Use sustainable storm water management, and providing pedestrian friendly paths and attractive open spaces with shaded places. Also, it can achieve by providing Sustainable transportation system, sustainable buildings, using renewable energy resources and sustainable wastes collection management.

This can be observed in many examples such as Detroit city which had its development face away from the river like Henery Ford's renaissance center which was a major corporate reinvestment. The river was used only for work tending through its services of the heavy industries, with its negative impacts on sight and greater pollution which affected not only the edge but the whole city. Also, like the bad effect on Belle Isle "Olmstedian Island Park", its bad status was changed by the new regeneration of the city and its waterfront by focused on the brownfield recovery areas, native trees and grasses replanting, pollution reduction of the river and banks and establish a continuous path of the public open green spaces and make the river edge as a welcoming area to the new investment and good urban life [15-21].

\section{URBAN WATERFRONT DEVELOPMENT PROCESS}

Urban waterfront development goes through different stages, to achieve the strategy objectives it is important to define the stages of the process to arrange the steps, partners and their financial responsibilities as following:

\section{Development conceptual vision}

It is the first stage to determine the direction of the development process according to the type, level, location and requirements of the waterfront toward identifying the opportunities locally and internationally. Therefore, the functions and needs can be organized according to the priorities, importance, which needs to remain- improverenewal.

\section{Layout of the waterfront}

Through the initial visualization and the context analysis (SWOT) it is important to:

-Determine the target area whether it is at the level of a small project or a level path or area level

-Taking into account the relationship between the target area (development project) and the surrounding area and the city to ensure that there is urban compatible between them. It can be achieved initially in the transportation network and infrastructure and others.

\section{Comprehensive development design}

Set up a suggested planning concept with alternative proposed designs taking into account:

-All aspects affecting the development process and the design of the target area in the future, it should include the economic, social, environmental and visual aspects achieving sustainable development.

-Identify all the involved parts and their responsibilities, beside financial requirements from them.

\section{Implementation mechanism and decisions priority}

After the Satisfaction of Vision and Objectives through the chosen alternative design, the methods for application should be Set by; creating a general unit for management control with cooperation between different parts (government, agencies, developers' team, nonprofit groups and the privet sectors), budget evaluated and achieving short-long term goals, All of that under the political and economic systems of the city.

The process of the waterfront development should include integrated urban waterfront development Standards that considered from reviewing literature study and the international examples as in Figure (1).

\section{THE CASE STUDY ALEXANDRIA-EGYPT}

Alexandria city is one of the most famous and important cities on the Mediterranean Sea. It became the second largest urban city in Egypt. It was built by alexander the great at 331B.C. it was the capital of Egypt for over 1000 years. Alexandria located in the north sector of Egypt. 


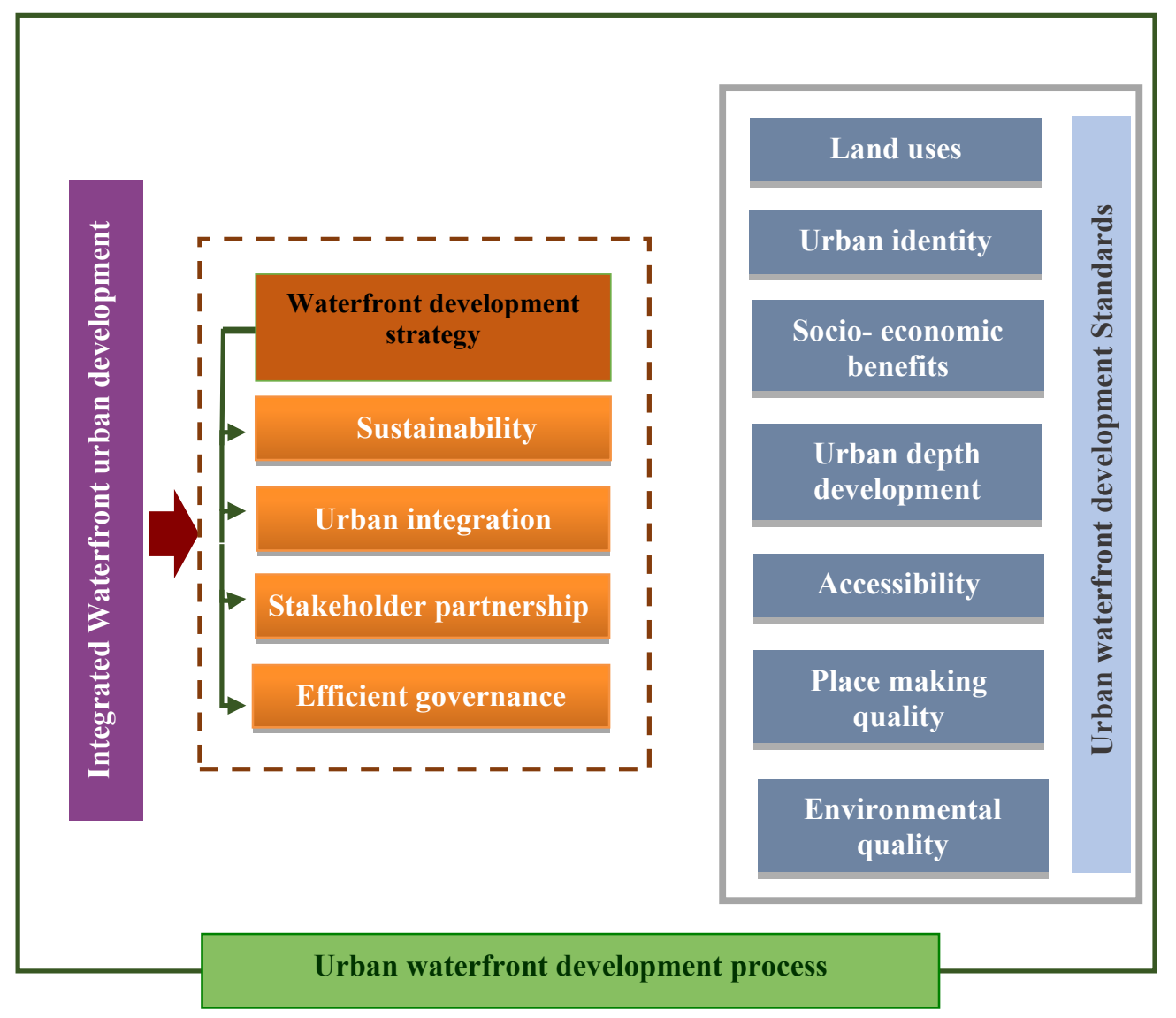

Figure 1. Proposed framework of the urban waterfront redevelopment. Source: authors

It occupied a T-shaped area about $2.818 \mathrm{~km} 2$ area which linked the Mediterranean Sea with along shore about $70 \mathrm{~km}$ to the Lake Marioutt [5]. It contains about 5.2 million inhabitants (2018) [35-10].

Through time, Alexandria has been growth especially its modern urban development growth from Mohamed Ali era 1805 that contains many areas and districts.

One of the most important and effective area is the central area which appeared at the beginning of 20th century and known as "Mahatet El-Raml" area [10-35].

It expanded through time and became the commercial and administrative center especially with the direct connection with the El-Raml tram and Masr train station and the existence of many hotels and restaurants which aimed the area visitors as in Figure (2).

"Mahatet El-Raml" area is part of the central district -one of nine districts of the Alexandria Governorate- [2], with unique waterfront which extends about $1.5 \mathrm{~km}$ along the sea. Because of its history, it contains main distinctive historic buildings and landmarks from various periods; roman, Coptic and Islamic, and adjust many other famous like Bibliotheca Alexandria [35].

While Alexandria city has varied economic base with a competitive advantage globally, and with its status as an important distention for about 3 million during the summer which including 10\% foreign tourists [35].
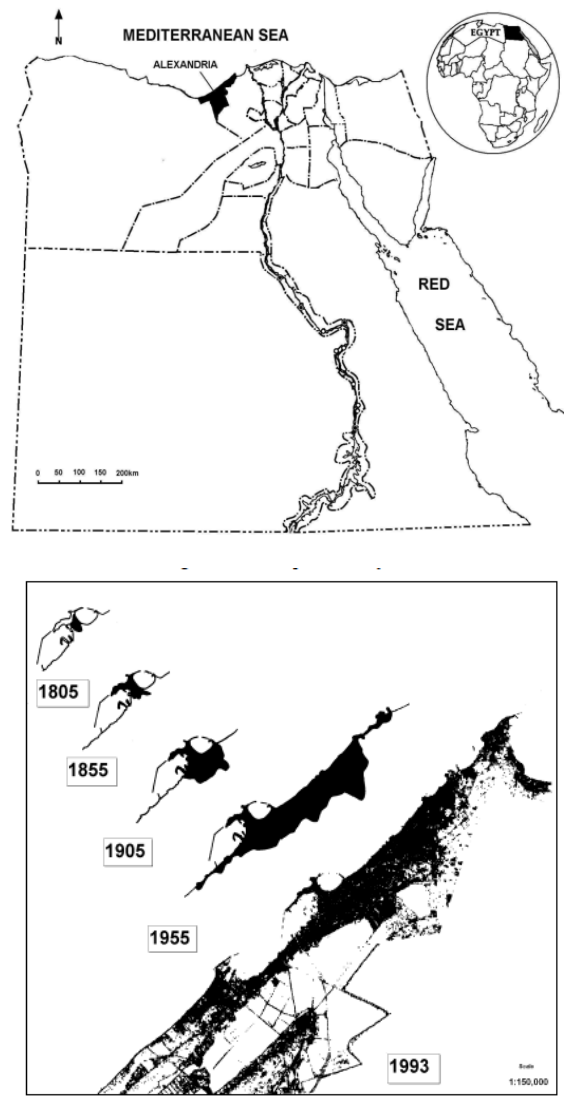

Figure 2. Alexandria location and its urban growth. Source: Azaz 2015 
The city center "Mahatet El-Raml" of Alex. is considered one of the important places to visit in Alex to enjoy its distinctive waterfront image due to its strategic location, its heritage iconic buildings like (Roman amphitheatre) (kom El-deka), open spaces, parks, restaurants, hotels, trades shops, offices, clubs, residential buildings, cinemas, Alex stadium, cathedrals and mosques, Alex national general court, Bibliotheca Alexandria and the train station as in Figure (3). aspects, And with the recent attempt to redevelopment of the city "SUP ALEX 2032" [1], it is important to consider the area of "Mahatet El-Raml" and its waterfront as a catalyst for the redevelopment plan of the city. So there is a need to study the area and its waterfront and putting improvement suggestions for its redevelopment.
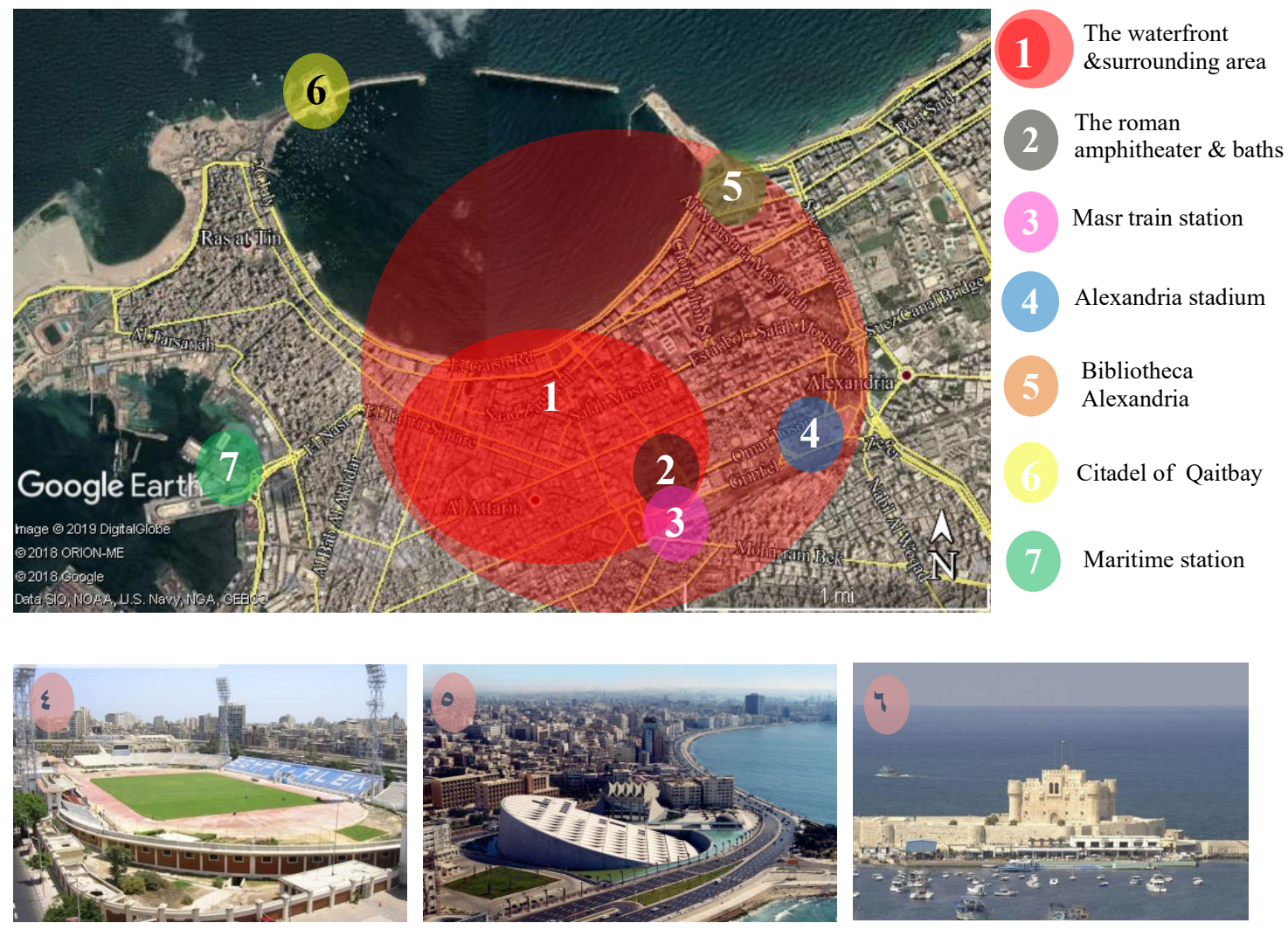

Figure 3. Mahatet El-raml waterfront and famous spots in surrounding area. Source: (google earth,2019- almasder,2019- ahaa,2019)

\section{A. The case study analyzing methodology}

Every Waterfront urban development strategy depends on the conditions and problems of each city and its waterfront condition. This analytical study using many tools; mapping analyses, the field observation finally, the reports information and previous studies that concerned in the area.

The methodology used in the study of the applied area is in following steps:

Although, considering the area of "Mahatet el-Raml" and its waterfront as an important destination for all visitors whether residents or tourists, with great potentials and opportunities to become distinguish waterfront locally and internationally because it's value as a center of commercial, administration and recreation activities.

But it has impairment that is take place nowadays, it faces many conflicts that negatively affect, such as; environmental damage and climate change, interest interference between stakeholders, waterfront character loss, funding shortage, absence of community participation, overloaded infrastructure and urban degradations in some areas, many attempts directed to enhance the city in many
1- Make the SOWT analysis for the chosen area according to its theoretical background and information in order to understand of the strength, weakness, opportunities and threats to be obligated in waterfront development process.

2- Analyze the current situation of the chosen area to present an assessment according to the analytical framework adopted through the theoretical part. This is done by analyzing the area based on the integrated urban waterfront development Standards that considered from reviewing literature study and how these standers can achieve the strategic objectives that defined as sustainability, stakeholder's partnership, urban integration and efficient governance.

3- Submit development suggestions based on integrated urban waterfront development Standards in order to achieve strategic objectives.

The proposed methodology is developed as a part of a development process and it is shown in the early stages of the waterfront development process, with the rest of stages applied during the implementation process. 


\section{B. SOWT Analysis of Mahatet El-Raml Waterfront}

\section{Strengths}

- The existing of the water as a strong visual determinant which catalyzes the city's development.

-The area is an important administrative commercial and entertainment center to the city and has a good derives of uses.

- The near of port, existence of tram and train station in the area is a potential for development the communication between the waterfront and the rest of the city.

- The existence of old unique buildings and valuable historic sites in the area.

- the existence of important services, cultural buildings, hotels such as Alexandria library, Alexandria stadium, museums, important mosques and churches which offer a good opportunity for tourism development.

- High percentage of population from youth under 20 years which represents a large workforce makes job creation the economic priority.

- Availability of open spaces squares and parks such as El shalalat park, El Khaldeen Park.

\section{Weakness}

-urban degradation and the old and historical buildings are at risk of being demolished.

- Lack of adequate efficient services and infrastructure and also, problems in mobility for the residence and summer visitors.

- Pollution of the sea water due to evacuate of untreated waste water and industrial wastes in the sea. In addition, several pollution problems are affecting public health.

- raising sea level is an environmental challenge.

- Weak of environmental awareness of the residence and lack of NGOs contribution in environmental programs. Conflict between some activities and uses

- Lack of beaches in the area and lack of good accessibility to water for the citizens.

- Congestion in the area and inadequate deterioration public transportation.

- Centralization of decision making, lack of citizen participation and lake of good governance.

- Lack of incentives to protect the important places that reflect value of the residence.

\section{Opportunities}

- The Alexandria SUP32 (participatory strategic urban planning for Alexandria city till 2032) which aims to produce a strategic urban plane of Alex city using participatory approaches.

- Hosting international council of museums 2022 and many local and international annual events and festivals.

- Possibility to coordinate between all stakeholders to make a holistic vision for the development of the area in the framework of SUP32.

- The potential to being international attractive touristic area due to existing of historical valuable locations.

- Possibility of development the mobility and connection with the city due to existing of tram and train stations.

\section{Threats}

- Weak state environmental department to deal with environmental treats.
- The need to financial recourse to cover the budget of the development process.

- Unfixable Law and legislations to deal with any future changes and in some time obstruct the development process.

- Lack of comfort and safety due to the improper traffic system.

- High population growth rate of $1.5 \%$ annually.

- Weak of citizen awareness of the waterfront development problems and weak of interest to participate in the development process

C. Analysis of Mahatet El-Raml Waterfront \& The Development Suggestions

In this part the research Analyses the current situation of the Mahatet El-Raml Waterfront to present an assessment according to the analytical framework adopted through the theoretical part.

This is done by analyzing the area based on the integrated urban waterfront development Standards that considered from reviewing literature study and how these standers can achieve the strategic objectives that defined as sustainability, stakeholder's partnership, urban integration and efficient governance.

Then the research Submits development suggestions based on integrated urban waterfront development Standards in order to achieve strategic objectives and improve the Mahatet El-Raml Waterfront in Alexandria city.

\section{DISCUSSION AND RESULTS}

Through, analysis of "Mahatet el-Raml" waterfront is according to the proposed framework the research sets some of the suggestions to improve the waterfront in attempt to achieve the strategy objectives. This can be summarized in:

- The various uses at the waterfront should be compatible with the uses of the surrounding area and the commercial management center without any conflicts. Thereof, it should be integrated with the economic concerns of the city and the SUP ALEX (2032) under achieving the Sustainability, Urban Integration, Efficient Governance, Stakeholder Partnership strategies.

- The absence of many activities in the area such as maritime and recreation activities especially with its narrow beach lead to suggest set a floating marine with increasing the beach width to contain many various activities, and like it with the rest of the area. These various activities should be compatible with the location of the waterfront, whether in terms of area, character or aesthetic and functional aspects, which enhances the existence of different investments that provide job opportunities and benefits for the city in the short and long term. This should achieve under sustainability and urban integration strategy.

Enhancing the identity of the area by renovating and improving historical buildings, archaeological sites and cultural activities, such as museums. Besides respecting of the other structures and buildings the identity of the area and the whole city that can be obtained by suggesting regulation and instructions taking on the account the identity of the city (colors, textures... etc.). This accomplishes, Urban Integration, Efficient Governance, Stakeholder Partnership strategies. 
TABLE I

Analysis of the Mahatet El-Raml Waterfront \& the Development Suggestions

\begin{tabular}{|c|c|c|c|c|c|c|}
\hline 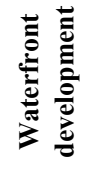 & & Mahatet El-Raml waterfront & 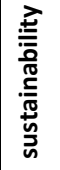 & 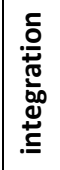 & 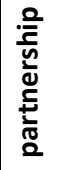 & 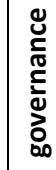 \\
\hline 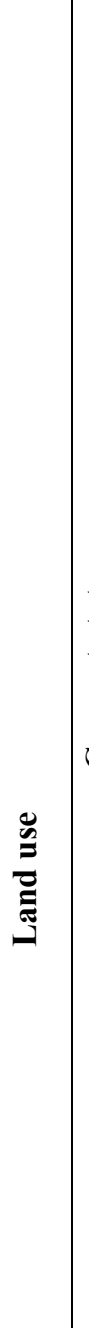 & 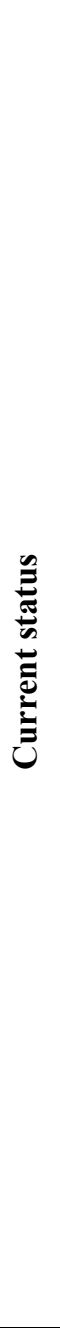 & $\begin{array}{l}\text { Although the area is a famous administrative, commercial and tourist } \\
\text { center in Alexandria which including important building such as the } \\
\text { Egyptian Chamber of Commerce in Alexandria and The roman } \\
\text { amphitheater, it suffers from; the deterioration of many uses, especially } \\
\text { public and recreational uses such as the cinemas and restaurants, the } \\
\text { interfere of the workshops within the residential and administrative } \\
\text { buildings and lack of services and facilities to carry out these activities in } \\
\text { the best manner as in Figure(4). } \\
\end{array}$ & & & & \\
\hline & 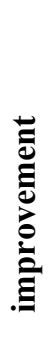 & $\begin{array}{l}\text { Ensuring the mixed uses and its diversity without conflict is the priority } \\
\text { of the development of the waterfront and the surrounding area, including } \\
\text { the uses of residential- shops- offices- hotels- cinemas and museums with } \\
\text { re-locating of workshops to suitable places surrounding with keeping its } \\
\text { benefits. } \\
\text { While promoting the use of entertainment and tourism through; the } \\
\text { provision of infrastructure, appropriate facilities such as transportation } \\
\text { and landscape elements in the site to serve both citizens and tourists. }\end{array}$ & $\sqrt{ }$ & $\sqrt{ }$ & $\sqrt{ }$ & $\sqrt{ }$ \\
\hline
\end{tabular}




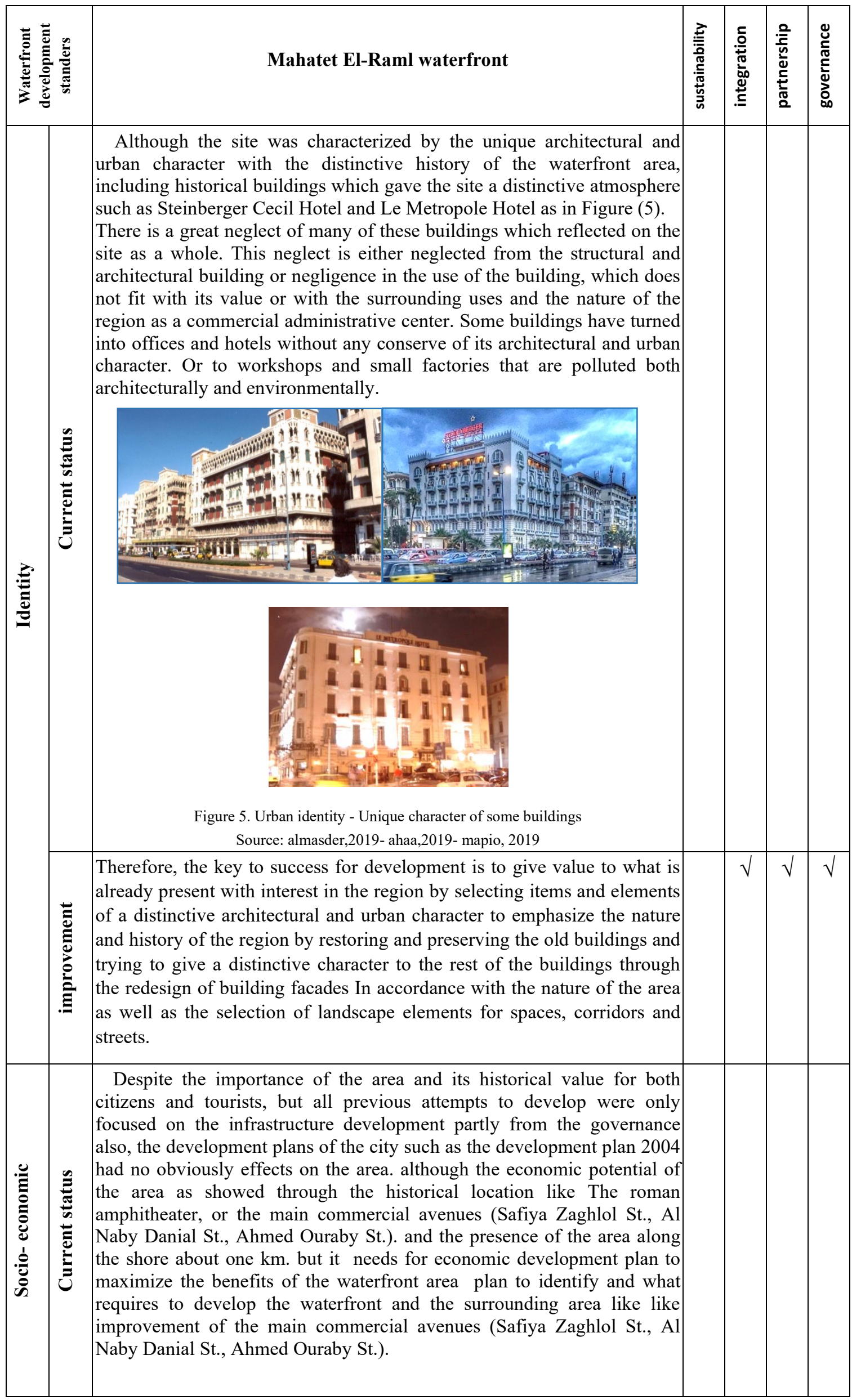




\begin{tabular}{|c|c|c|c|c|c|}
\hline 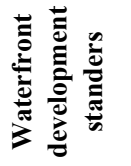 & Mahatet El-Raml waterfront & 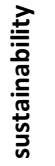 & 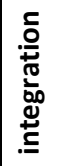 & 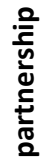 & 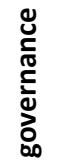 \\
\hline 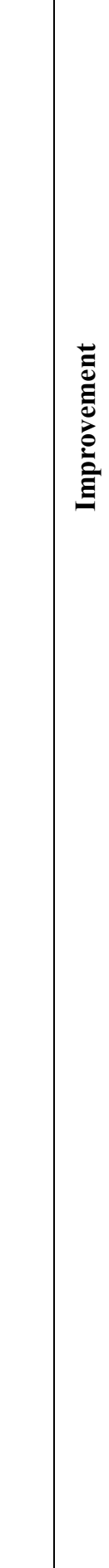 & $\begin{array}{l}\text { By creating a viable business base to achieve financial self-sufficiency } \\
\text { with waterfront employment creation. So, It is necessary to develop a } \\
\text { long-term economic development plan not only short-term plans just for } \\
\text { fast benefits. This can achieve by establish many projects such as tourism } \\
\text { projects; public centers, floating marina, floating hotels and cinemas, or } \\
\text { improve the existing ones in the area. As well as the long benefits from } \\
\text { establish of some non-polluting craft workshops to produce traditional } \\
\text { products but without conflicts with other. In addition, organize special } \\
\text { events and seasonal activities during different feasts and promotions like } \\
\text { the International Council of Museums (ICOM) which planning to host at } \\
\text { 2022. This makes users feel welcome and safe to ensure repeat visit by } \\
\text { them which is essential of sustainable commercial growth. Also, a high } \\
\text { level of access and extend the trading hours of business and visitor } \\
\text { attraction support the commercial success. Besides that, it is important to } \\
\text { set a design vision for the of water edge development by design open } \\
\text { areas, commercial booths, tourist boat centers and etc. as in Figure (6). } \\
\text { It is necessary to take into account the area's ability to compete globally } \\
\text { because of the fame of the city and its historical importance, with } \\
\text { increasing the interest in the area and its distinctive identity by the } \\
\text { provision of all uses to ensure the quality of the place frequented by both } \\
\text { citizens and tourists. Also, create or improvement brands projects on the } \\
\text { waterfront area to reinforce the economic value of the waterfront urban } \\
\text { image. }\end{array}$ & $\sqrt{ }$ & & $\sqrt{ }$ & $\sqrt{ }$ \\
\hline
\end{tabular}




\begin{tabular}{|c|c|c|c|c|c|c|}
\hline $\begin{array}{l}0 \\
0 \\
0 \\
0\end{array}$ & & Mahatet El-Raml waterfront & 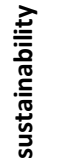 & 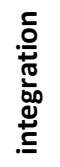 & 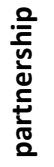 & 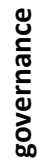 \\
\hline 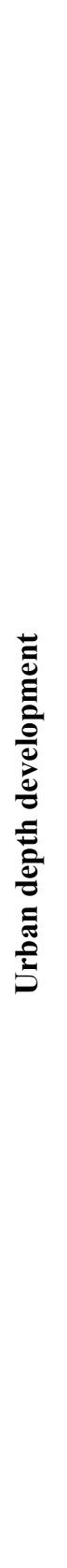 & 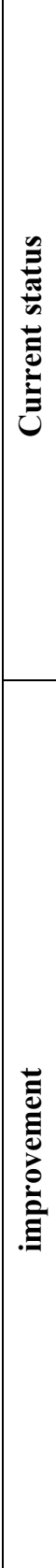 & $\begin{array}{l}\text { By increasing the physical, functional, social and visual integration of } \\
\text { the waterfront development project with the rest of the city and extending } \\
\text { the visual and physical linkage from the waterfront to the city can be } \\
\text { achieve by: } \\
\text {-developing some integrated city infrastructure such as roads, public } \\
\text { transportation systems and equipment and services like improving Masr } \\
\text { station and El Raml tram station. } \\
\text {-extending streets, roads, pedestrian networks, access and connections by } \\
\text { the location of the tramline, transit and railway station. Also, extending } \\
\text { the neighborhoods, parks, and open spaces to link the waterfront to large } \\
\text { systems like Al Shalalat Park. } \\
\text {-create a new city center in the waterfront by providing new functions and } \\
\text { activities, new buildings with new character consistent with the character } \\
\text { of the Alex city. } \\
\text {-the zone of the waterfront development project extends to the depth of } \\
\text { Alex city about } 1.5 \text { km not just a thin line. So, the development zone } \\
\text { includes various functions and activities like the main commercial } \\
\text { avenues (Safiya Zaghlol St., Al Naby Danial St., and Ahmed Ouraby St.). } \\
\text { Beside the proposed floating marina which expends in the sea. } \\
\text {-The management of the waterfront development project as a part of the } \\
\text { development of the city is recommended. }\end{array}$ & $\sqrt{ }$ & $\sqrt{ }$ & & $\sqrt{ }$ \\
\hline 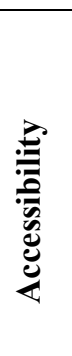 & 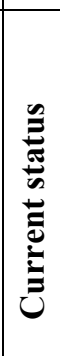 & $\begin{array}{l}\text { Although the exist of El-Gaish road" the axe of } 26 \text { July"which is the } \\
\text { main road that extend along the waterfront and the parallel of it is Omar } \\
\text { Lotfy which considers one of the main road in Alex. } \\
\text { With Many main streets extend Perpendicular on this road such as } \\
\text { Safiya Zaghlol Street, Al Naby Danial Street and Ahmed Ouraby Street, } \\
\text { but there is a mobility problem for the visitors because of the reduction } \\
\text { and detritions of the streets whether parallel or perpendicular to the } \\
\text { waterfront. }\end{array}$ & & & & \\
\hline
\end{tabular}




\begin{tabular}{|c|c|c|c|c|c|c|}
\hline \multicolumn{2}{|c|}{ 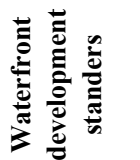 } & Mahatet El-Raml waterfront & 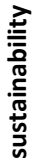 & 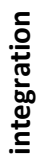 & 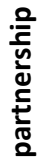 & 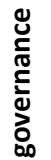 \\
\hline & 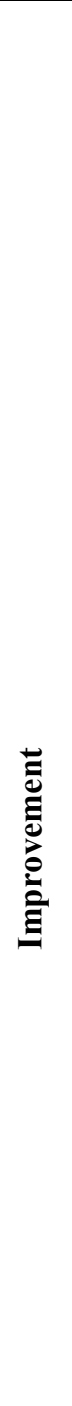 & 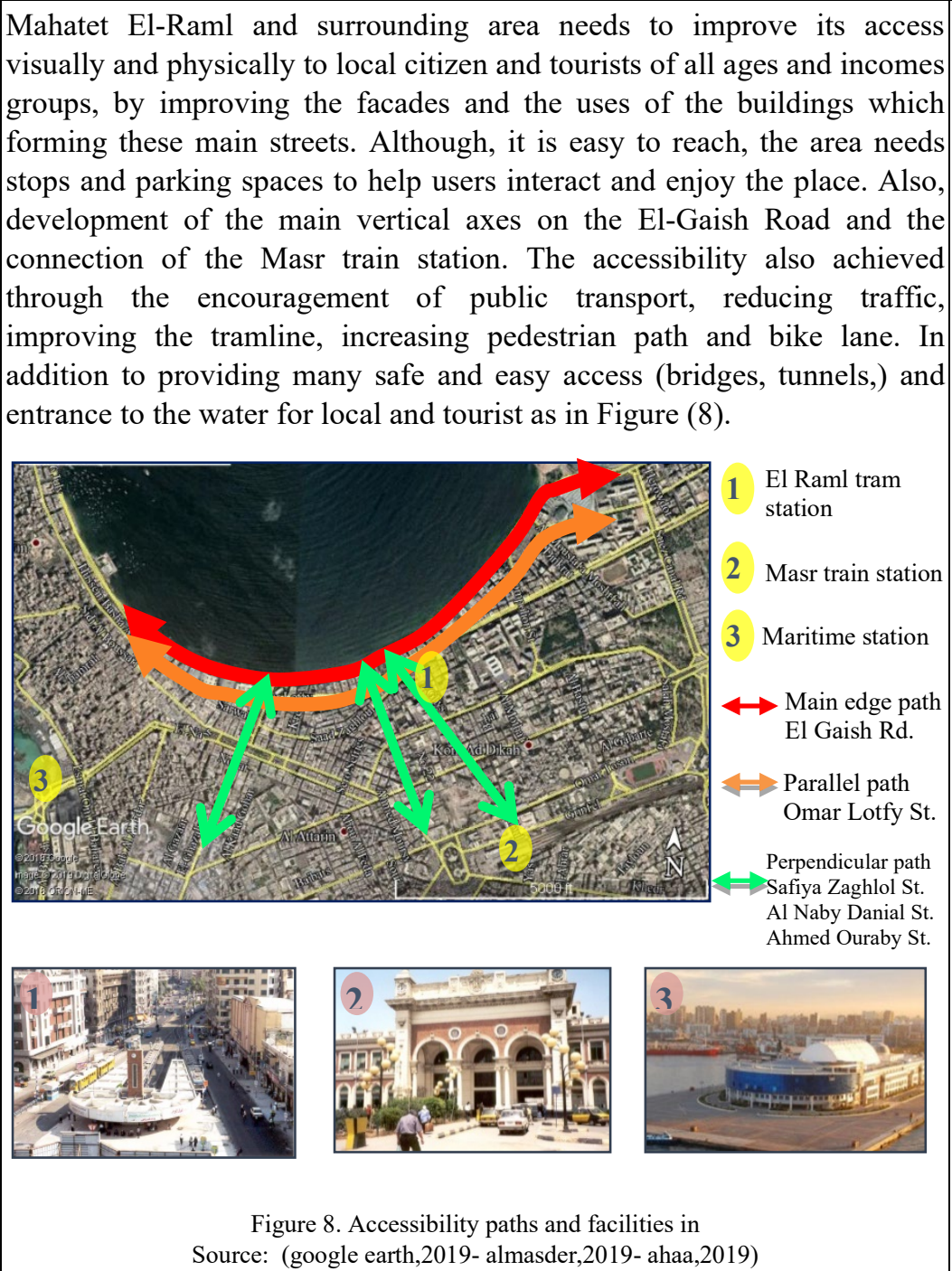 & $\sqrt{ }$ & $\sqrt{ }$ & & $\sqrt{ }$ \\
\hline & 苞 & $\begin{array}{l}\text { Livable area } \\
\text { Although, The waterfront area has many open spaces, squares and parks, } \\
\text { it suffers from the impairment of it and the lack of the maritime activates } \\
\text { because of the narrow shore in this area. }\end{array}$ & & & & \\
\hline 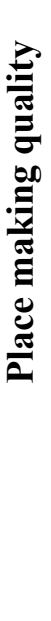 & & $\begin{array}{l}\text { To make Mahatet El-Raml waterfront as a livable area: } \\
\text {-create public spaces with opportunities for recreation activities, } \\
\text { waterfront activities bringing visitors and citizens back to the waterfront } \\
\text { edges like improvement the main streets and squares like Saad Zaghlol, } \\
\text { entertainment parks on the waterfront like El Shalalat park \& Al Ssaa } \\
\text { square by establishing services and activities and includes the different } \\
\text { residential zones. } \\
\text {-create floating marina and platforms to define new edges with the } \\
\text { waterfront which create opportunities to new water activities such as } \\
\text { costal ferry and terminals and bout trips. } \\
\text {-improve the streetscape and street furniture which help to increase the } \\
\text { social interactions and social activities. And reduce the motors } \\
\text { movement and encourage walkability to achieve livable eligible, attractive } \\
\text { waterfront. Figure (9) }\end{array}$ & $\sqrt{ }$ & $\sqrt{ }$ & $\sqrt{ }$ & $\sqrt{ }$ \\
\hline
\end{tabular}




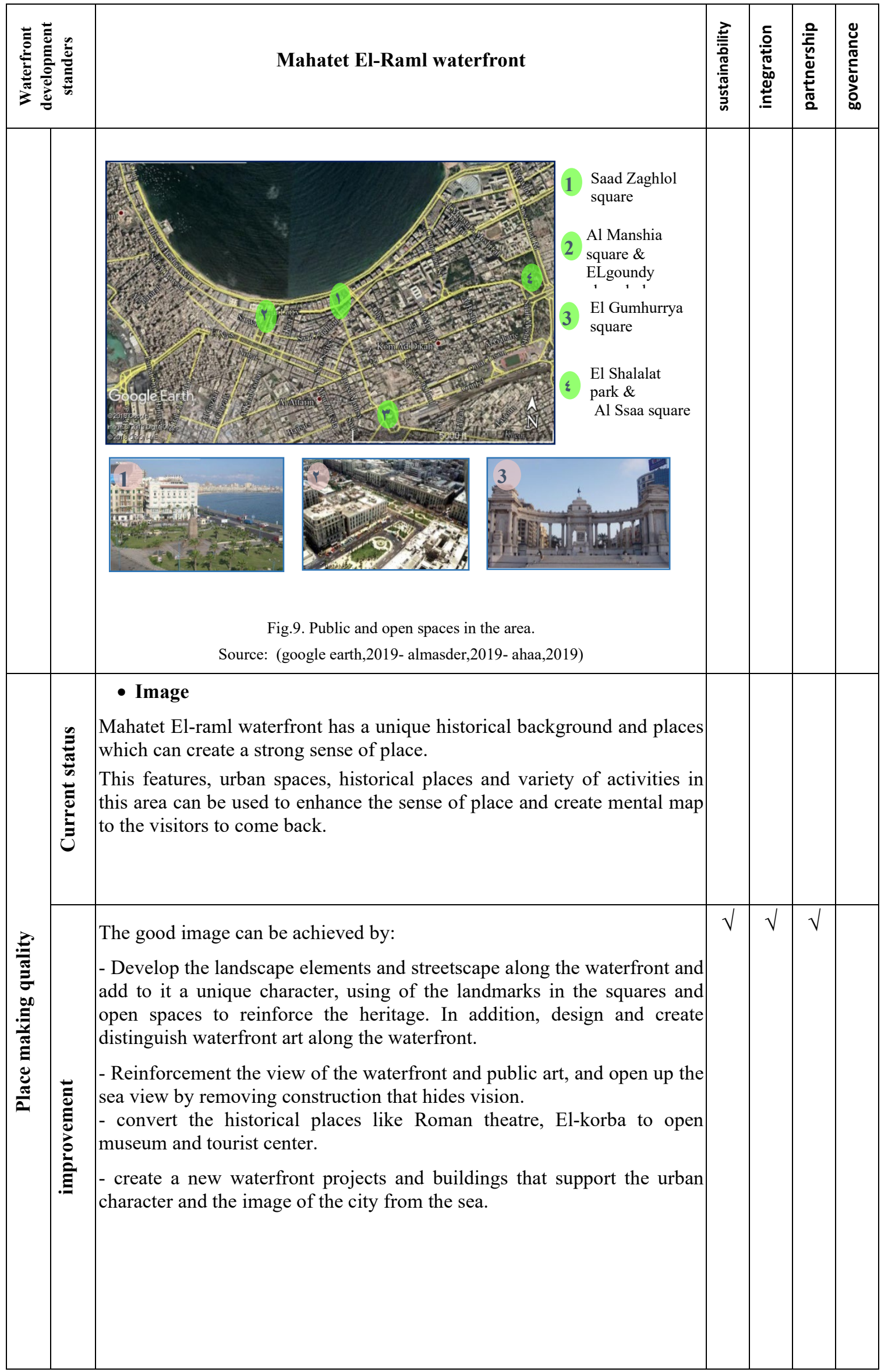




\begin{tabular}{|c|c|c|c|c|c|c|}
\hline \multicolumn{2}{|c|}{ 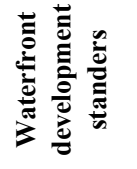 } & Mahatet El-Raml waterfront & 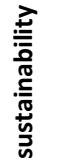 & .0. & 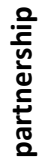 & 㫕 \\
\hline \multirow{7}{*}{ 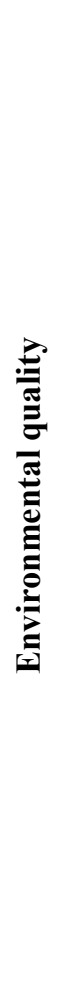 } & 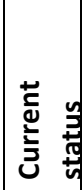 & $\begin{array}{l}\text { Area suffers from many environmental problems because of the water and } \\
\text { air pollution and the threats of rise the sea level }\end{array}$ & & & & \\
\hline & \multirow{6}{*}{ 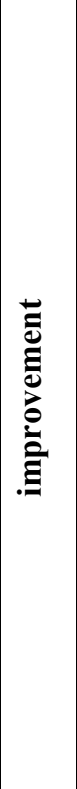 } & $\begin{array}{l}\text { The waterfront development program of the chosen site has to be } \\
\text { sustainable environmental management program to enhance the quality of } \\
\text { the environment in the city, it can be achieved by: }\end{array}$ & $\sqrt{ }$ & $\sqrt{ }$ & $\sqrt{ }$ & \multirow[t]{6}{*}{$\sqrt{ }$} \\
\hline & & $\begin{array}{l}\text {-cleaning the water regularly along the waterfront and remove trash tidal } \\
\text { wreckage from the water to improve water quality and conserve the } \\
\text { aquarium life. }\end{array}$ & & & & \\
\hline & & $\begin{array}{l}\text { - using sustainable infrastructure along the water and sustainable green } \\
\text { transportation options such as pedestrian paths, bike lanes, and public } \\
\text { transit. }\end{array}$ & & & & \\
\hline & & $\begin{array}{l}\text {-reduce using the non-renewable natural resources and improve energy } \\
\text { efficient, infrastructure and energy efficient buildings. }\end{array}$ & & & & \\
\hline & & $\begin{array}{l}\text {-provide open spaces and parks increasing greenery areas with trees, } \\
\text { brushes, green spaces in order to reduce urban heat island, improve air } \\
\text { quality and providing shaded areas protected from sun and rain. }\end{array}$ & & & & \\
\hline & & $\begin{array}{l}\text {-using sustainable program for waste management and increase using gray } \\
\text { water and material from sustainable and local sources for streetscapes. } \\
\text { - creating barriers to protect the shore against tidal damage without } \\
\text { harm the aquarium life. }\end{array}$ & & & & \\
\hline
\end{tabular}

- Use a sustainable approach to waterfront development by taking into account the consumption of energy and resources, the use of renewable sources of energy, the improving of air and water quality, the preservation of aquatic life and the deal with the climate change. This should be achieved under sustainability, Efficient Governance, Stakeholder Partnership strategies.

- Public access to the waterfront by providing public transport to provide physical access and provide visual clarity of the roads and paths leading to the waterfront and the surrounding area by improve the tram station, providing number of bus stations and adequate parking lots. This accomplishes Urban Integration, Efficient Governance, Stakeholder Partnership strategies.

- Considering the waterfront area as a vital and livable area that the public feels safe and comfort, and attentive to the public- right of way. It can be achieved by establish new places for various activities and providing the elements which make the visitors experience at the area more comfortable and pleasant. This should be achieved under sustainability, Efficient Governance, Stakeholder Partnership strategies

- Attention to visual and aesthetic considerations and give a distinctive visual image of the area and the city, whether for the waterfront urban image or improve the landscape of the area and the city globally. This accomplishes Urban Integration, Efficient Governance and Stakeholder Partnership strategies.
Through the literature study and after analyzing the study area of Mahatet El-Raml waterfront in Alexandria city, several conclusions have been highlighted which confirmed on the impotence of the urban waterfront development Standards to achieve the objectives of Waterfront development strategy in the frame of urban waterfront development process.

\section{REFERENCES}

[1] AFD. (2018). Alexandria: Regenerating the city- A contribution based on AFD experiences, Agence Française de Développement.

[2] Alexander, Ian. Sharma, Narasimha. (2012). Redevelopment Projects at the Urban-Marine Interface in Vancouver, BC. Master of Marine Affairs. University of Washington.

[3] Al-Shams, Ahmed Raad. Et al. (2013). Waterfront Development within the Urban Design and Public Space,Framework in Malaysia. Asian Social Science. Vol.9, No. 10. Published by Canadian Center of Science and Education.

[4] Amola G., (2006) Contribution of waterborne public transport to sustainable waterfronts. Stockholm: Department of Urban Planning and Environment.

[5] Azaz, Lotfy (2015), Dilemma of Vibrant City and Endless Urban Growth, Lessons from Alexandria, Egypt, REAL CORP

[6] Brahmi, M. (2017) Water Bodies within the Metropolitan Cities: Understanding the Urbanization Process around Lakes \&Lagoons 'shores in Greater Tunis, towards sustainability, Master of Science in Integrated Urbanism and Sustainable Design, University of Stuttgart.

[7] Brett, E.A., (2000), participation and accountability in development management, the journal of developments studies. P.1-29.

[8] Bruttomesso, Rinio. (2006) Waterfront redevelopment a strategic choice for cities on water. International Waterfront Speakers Luncheon IV. 3.

[9] Butuner,B. (2006), Waterfront Revitalization as a Challenging Urban Issue. 42nd ISoCaRP Congress. 
[10] CAPMAS. 2017, National Census book for population and buildings,

[11] Chen, Chien-Hua. (2015), the Analysis of Sustainable Waterfront Development Strategy - The Case of Keelung Port City, International Journal of Environmental Protection and Policy.

[12] Chill Huang, W., Ken Kao, s. (2014) Public- Private Partnerships during waterfront development process: The example of the world exposition, Ocean \& costal Management 92, P.28-39.

[13] Cooperative governance: department of cooperative governance and traditional affairs, Republic of South Africa (2016). Integrated Urban Development Framework. Publish by, COGTA,

[14] Costa, João Pedro. (2002), the new waterfront: segregated space or urban integration? Levels of urban integration and factors of integration in some operations of renewal of harbor areas w@terfront > 2002: The Arts in Urban Development Waterfronts of Art II. ANEJO I. p.6-33

[15] Develop River town, (2012). 11.75 Acres of Detroit Waterfront Development Opportunity.2012

[16] Hradilová. (2012), Influence of Urban Waterfront Appearance on Public Space Functions, ACTA Universitatis Agriculturae et Silviculturae Mendelianae Brunensis. Volume LX. Number 8.

[17] Hussein, R. M. R. (2014), Sustainable Urban Waterfronts Using Sustainability Assessment Rating System. World Academy of Science, Engineering and Technology, International Journal of Civil, Environmental, and Structural, Construction and Architectural Engineering Vol: 8, P.488-498.

[18] Jones, A. (2013), Urban waterfronts: learning from legacies lessons from the past pointers for the future. Regenerating Maltese and Sicilian Waterfronts: Perspectives from Two Mediterranean Islands, conf. Kalkara. P.1-16.

[19] Korbee D., Mol A.P.J. et al., (2015) Ecological consideration in constructing marine infrastructure: The Falmouth cruise terminal development, Jamaica. Marine Policy. 56:23-32.

[20] Kostopoulou, Stella.( 2013),On the Revitalized Waterfront: Creative Milieu for Creative Tourism. Sustainability. 5. www.mdpi.com/journal/sustainability

[21] Krieger, A. (2003), Principles for Remaking the Urban Waterfront Austin, Texas -. Principal, NBBJLindmäe, Maria. (2014), Urban Waterfront Regeneration and Public Participation. Confrontation or Cooperation? The Case of Kalarand, Tallinn. Master of Arts in Spatial Planning and Population Studies. Faculty of Literature. Universitat Autònoma de Barcelona Barcelona.

[22] Liu, Huirong.(2013) Establishing Local Identity through Planning and Landscape Design in Urban Waterfront Development, Master of Landscape Architecture. Guelph. Ontario. Canada.

[23] Marshall, Richard. (2001), Waterfronts in Post-industrial Cities, published by Spon Press.

[24] Ministry of Housing, Utilities and Urban Development, (2010) Prepare a comprehensive overview of housing issues and monitor changes in the housing market-Alexandria city

[25] Niemann, B. \& Werner, T. (2016) Strategies for the sustainable urban waterfront. the 11th International Conference on Urban Regeneration and Sustainability WIT Transactions on Ecology and The Environment. Vol 204. WIT Press. www.witconferences.com

[26] Papatheochari, D. 2011, Examination of Best Practices for Waterfront Regeneration Littoral. EDP Sciences.

[27] Plöger , Jörg. (2008), Bilbao City Report, Centre for Analysis of Social Exclusion An ESRC. ref $x$

[28] Port Melbourne. (2013), Waterfront Urban Design Framework, city of port Phillip, Australia. www.portphillp.vic.gov.au/port-melbouneudf.htm

[29] Pramesti, Rochana Esti.(2017) Sustainable Urban Waterfront Redevelopment: Challenge and Key Issues. Media Matrasain. Volume 14. No.2.

[30] Radosavljević, Uroš. , (2008) Conditions Influencing Waterfront Development and Urban Actors Capacity as a Strategic response. Spatium. P. 78-83

[31] Ragheb, Riham A., (2017), Sustainable Waterfront Development-a Case Study of Bahary in Alexandria, Egypt. Journal of Civil Engineering and Architecture 11 380-394

[32] Roux, R le. (2015), an exploration of the role of waterfront development in urban regeneration: Mossel Bay as case study. Magister Artium et Scientiae in Urban and Regional Planning at the Potchefstroom Campus of the North-West University.

[33] Rukiah S, Zainora M,Green (2012), infrastructure in waterfron development toward achieving sustainable environment the case of Muar Riverside, Malaysia, Kuala Lumpur: international Islamic University Malaysia, p.1-6.

[34] Russo, Michelangelo. Formato, Enrico. (2014) City/Sea Searching for A New Connection Regeneration Proposal for Naples Waterfront Like an
Harbourscape: Comparing Three Case Studies. TeMA Journal of Land Use, Mobility and Environment.

[35] Shamsuddin, S., Latip N. S. Abdul, et al. (2008), Waterfront regeneration as a sustainable approach to city development in Malaysia. The Sustainable City. WIT Transactions on Ecology and the Environment, Vol 117, (C) 2008 WIT Press, p.45-54

[36] Sirry, Azza.2018, ALEXANDRIA: DEVELOPMENT CHALLENGES OF A COASTAL SECOND CITY, CIDOB

[37] Tungka, A., Omran A., et al. (2012), Manado Waterfront Development Concept as Sustainable City of Tourism. Acta technica corviniensis Bulletin of Engineering. Fascicule 2. P.31-36.

[38] Urban Design Report 1. 2002, Toronto Report of the Results. Waterfront Design Initiative

[39] Yassin, Azlina. , Razali,Najib. , et al., (2013) Examining Governance for Waterfront Development in Malaysia. International journal of business and society. vol. 14 No.3, 358-367

[40] Yıldiza, R., et al. (2015) Sustainable Urban Design Guidelines for Waterfront Developments. 2nd International Sustainable Buildings Symposium. 28-30th May Ankara - Turkiye. p.487-494.

[41] Yue, B. (2006), Research Centre Planning and New Use of Waterfront Space A Case Study of East Darling Harbour, Bachelor. Thesis of Planning and Urban Development Program University of New South Wales.

Web Sites

Google earth

www aaha ch

www.alexandria.gov.eg

www.almsdar.net

www.eldwly.netwww.mapio.net 